\title{
Studia Cingarorum - romológia a gyakorlati tudásforgalmazásban
}

\author{
A. GERGELY ANDRÁS ${ }^{1}$
}

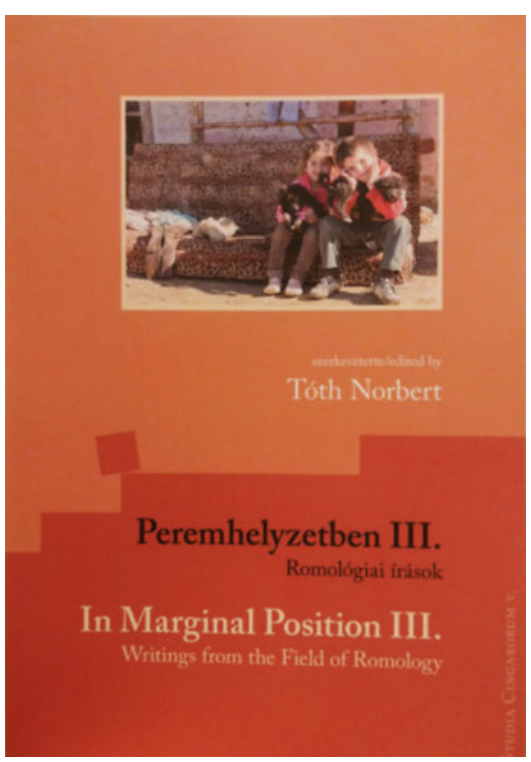

Egy kevéssé közismert, mégis alaposabb figyelemre érdemes kötetről kell szólni az elismerés - és legalább annyira az elmélyült érdeklődés - hangján: Tóth Norbert szerkesztésében a Debreceni Egyetem adott ki tanulmánykötetet Peremhelyzetben III./In Marginal Position III. ${ }^{2}$ címen, romológiai írásokból. A kétnyelvű kötet (ez esetben nem ugyanazok az írások szerepelnek két nyelven is, hanem a magyar dolgozatok angolokkal egészülnek ki) az egyetem Gyermeknevelési és Gyógypedagógiai Karán (a Lippai Balázs Roma Szakkollégium keretei között) indult kutatások utóbbi anyagaival, melyek a tizenöt éve folyó „romológiai, a kisebbségi cigány közösségek kultúráját, társadalmi viszonyait és együttélési kapcsolatrendszerét elemző" tevékenység eredményei, s ezeket (mint az előző két kötetet is) a Studia Cingarorum sorozatban jelentetik meg. E kötetek a romológiai kutatások tapasztalatait kívánják „a gyakorlati társadalomtudományi alkalmazásának lehetőségére” figyelemmel „a szélesebb közönség számára is hozzáférhetővé tenni”, ezzel egyszersmind esélyt kínálva a szakembereknek, „hogy munkájukat bemutassák és a tudományos kutató és elemző tevékenység konkrét társadalmi jelentőséget az integráció, illetve a társadalmi felzárkózás összefüggésében értelmezzék". (7. oldal)

Tudatos szerkesztési cél, hogy a debreceni karon „folyó képzések (cigány-roma nemzetiségi óvodapedagógus, szociálpedagógus) szakirodalmi kínálatát bővítse”, egyúttal más, például a „határon túli magyar tannyelvű felsőoktatási intézmények

${ }^{1}$ ELTE TáTk Kulturális Antropológia Tanszék, e-mail: andrasgergelya@gmail.com

${ }^{2}$ Tóth Norbert (szerk.) (2018): Peremhelyzetben III. Romológiai írások. In Marginal Position III. Writings from the Field of Romology. Didakt Kft., Debrecen, 279 oldal. 


\section{RECENZIÓ}

társadalomtudományi szakjain" folyó oktatási programokhoz is valamelyest segítő, kutatási és megértési modelleket népszerűsítő háttéranyagot kínáljon a kötet és a sorozat. Nem mellékes tehát a cél, hogy a könyvsorozat „a magyarországi és a határon túli magyar többségi környezetben élő cigány-roma kisebbségi közösségek társadalmi integrációjának ügyét, valamint az ezzel kapcsolatos hazai kutatásokat, esettanulmányokat” segítsen elő, s a kétnyelvűség része annak is, hogy „lévén a téma az Európai Unió kiemelt társadalompolitikai célterülete - a nemzetközi közvélemény számára is láthatóvá tegye". E kötetben a Karon megrendezett nemzetközi konferencia (Kihívás és/vagy esély - A romák integrációja Európában, 2017) előadásai szerepelnek egymás után, nem tagolva tematikus vagy más rendszerbe. Ez azonban a hasonló köteteknél megszokott megoldás - a kutatói és elemzői státusz, a közlések címei már magukban is körvonalazzák tartalmukat.

A tizenhat előadás (huszonegy szerző) a legeltérőbb aspektusokat is egymás közelébe engedő megközelítési módjai a recenzensnek sem kínálnak többet, mint egyenkénti ismertetést. Erre azonban itt a tér is, az idő is csekély, nem utolsósorban pedig a szerzői tónus, a vizuális háttér, a szövegszerű idézetek, az ábrák és táblák, alapos bibliográfiák sokszínűsége csak érdemtelen „kivonat” elkészítésére késztethetne. Fontosabbnak látom az írások összhangjának, a szemléletmódnak megfogalmazását, mely egyúttal több dolgozatot is egyberendel, mintegy „összeolvasásuk” vagy párhuzamos tárgyalásuk válik így lehetővé.

$\mathrm{Az}$ „összeolvasás” persze nem előzmények nélküli. Két apropóból sem az. Egyfelől a sorozatban korábban megjelent kötetek már részben „előkészítették” a tematika helyénvalóságát: a sorozatban eddig megjelent Bocsi Veronika szerkesztette Peremhelyzetben. Romológiai írások kötet (2015), valamint a Biczó Gábor és Bálint Péter összeállította Peremhelyzetben II. Romológiai írások (2017) már tematikusan hangolták a mostani kiadvány tudományos horizontján elfoglalt megismerői pozíciókat, továbbá a Láczay Magdolna szerkesztette Az esélyteremtés missziója. Tanulmányok a roma közösségi kultúra hagyományairól és a tehetséggondozásról (2015) és a Pálfi Sándor összeállította Roma gyermekek nevelése és segítése (2015) ugyancsak állapot-ábrát kínált a romológia tudásterében akuttá váló kérdések részválaszaihoz. De a másik szempont sem mondható mellékesnek (túl a pályázati vonzáskörön és a résztvevők számára is Európa vonzásköre, az emberi jogi, kisebbségjogi és állampolgári partnerségi lehetőségek közvetlen körén). Ez pedig a lehetséges és szükséges összehasonlítási horizontok találkozása. Az összevetés idői és térbeli viszonyrendszert is meghatároz: egyszerre van jelen a térbeliség az időben Jenei Teréz: Ciganológiai kutatások Oroszországban (27.), Nagy Pál: A cigányosztályok indításának politikai és pedagógiai dilemmái az 1950-es években (83.), María José Andrade: The weight of history on the Roma situation in Europe: the case of the Spanish Gitanos and their legal status (241.), Bálint Zsuzsa: „Folktales with interspersed songs” - comparative analysis of the Singing Bone tale type in some Spanish and Hungarian Gypsy variants (265.) című tanulmányában, és meghatározó momentum az időkomponens a térben 


\section{RECENZIÓ}

Anikó Vida: Benefit recipients or citizens? Changes in the notion of unemployment in Hungarian parliamentary debates in two decades: 1991-2011 (139.), Draženko Tomić - Vladimir Legac: Dealing with the Roma Issue in the Magazine Kršćanska obitelj (Christian Family) (Mostar, 1900-1920 and 1938-1944) (181.), Eugenia I. Ivanova - Velcho Krustev: The tinkering - the handicraft, that integrate gypsies toward neighboring in Bulgaria (209.) című elemzésekben.

A téri és időtagoltság mint konstrukciós elem ugyanakkor nem hiányzik a strukturális, avagy intézményi és kulturális közösségi dimenziók körére épülő írásokból sem. Ezekben a pedagógiai, adaptációs, esélyegyenlőségi, kompetenciateremtési, értékszemléleti szempontok kapnak méltó hangot és elemző aspektust, ilyenek Benedek Katalin: Esélyteremtés és vizuális kompetencia (9.), Lehmann Miklós: Integráció és világháló (39.), Máté Dezső: Generációs változások a Roma diplomások életútjában, a társadalmi reziliencia hatása (49.), Mező Ferenc: Alulteljesítő tehetséges roma tanulók azonosításának és ellátásának pszichológiai, pszichopedagógiai aspektusai (71.), Oláh Dezső: Cigányok a római katolikus egyház és a kisegyházak célkeresztjében (107.), Orsós Anna: Romológia a felsőoktatásban (125.), Andras L. Pap: Conceptual paradigms and policy discourses on the Roma in Hungary - and beyond (149.), Edina Berta Héderné: Who is served by child welfare services? Power as an agent in the changes in the content of personal help (193.), Mihály Fónai - Lajos Hüse - Erzsébet Balogh - Andrea Toldi: School integration, inclusion and exclusion: experiences of empirical researches (221.) címú írások.

Jóllehet, az ilyenfajta „elnagyolt” vagy elnagyoló áttekintés nem hoz túl sokat sem a Szerzőknek, sem az Olvasóknak - azon a téren, mit is keressenek a könyvben, miért is kell figyelemmel követni azt, ami a roma kutatások látszólag háttérterülete, s a velük foglalkozásnak is csak keveseket érintő marginális tere. Meglátásom szerint (nem nagy felfedezés ez, csak megerősítő...) főképpen azért, mert a cigánykutatások megannyi évtizede sem volt elegendő ahhoz, hogy érvényes tudást szerezzünk a roma kisebbség - akár bármely létkérdésének, de mindenekelőtt - integrációs helyzetének, adaptációs megoldásainak, partnerségi útválasztásának vagy az ezt elutasító távolságtartásának alapkérdéseiről. Amikor az iskolai integráció is egyszerre kicsuk és bezár (Fónai, Hüse, Balogh, Toldi), amikor a gyermekjóléti alapkérdések legjava cigányoktatási problémakör (Héderné), vagy a mindennapi életvezetés alkalmazkodást elősegítő „politikáin”, pedagógiai „rejtett tantervein” múlik (Pap, Benedek, Orsós) a „felzárkóztatást” elősegítő tevékenységek strukturális elgondolása is akkor már lassan fontosabb kérdéssé válik: létezik-e még az a („többségi társadalom” vagy „integrált” és „nemzeti” eszmény, amelyhez egyáltalán adaptációs modellek dolgozhatók ki. S ez esetekben lehet kulcskérdés, alapkompetenciák szempontja az egyházak funkcióvállalása (Oláh, Ivanova - Krustev), a tehetséggondozás felelőssége (Máté, Mező, Lehmann, Pap, Héderné), továbbá a kortárs világjelenségekhez alkalmazkodás kihívásainak megtanítása (Benedek, Lehmann, Mező, Orsós, Vida, Héderné), s hasonlóképpen fölerősödik a kötet egészének egyik meghatározó aspektusa: 


\section{RECENZIÓ}

mindezek ismerete és kutatása mint kulcstevékenység. S miként Jenei Teréz az orosz ciganológia kutatásának felelősségét a 20. századi csekélyke eredmények és „népi kultúra” vagy „szubetnikum”-kérdés felől a komparatisztika és a szociálantropológia felé megtett lépések előnyeivel világítja meg, vagy ahogyan Bálint Zsuzsa a mesei hősök és maga a történetmesélés kultúrák közötti átíveléseit bemutatja a népmesei motívumok történeti változói révén, az is jelzi, mennyiféle párhuzamosan is releváns kérdés rejtőzik a ma még nem kellőképpen ismeretes kutatások háttérvilágában.

A kötet ezzel is, a romológiai kutatás számos új témakörének, oktatásának, megismerési folyamatának újabb szaktudományi problematikáját földolgozó szándékokkal is (továbbá nem feledendő: a kutatás horizontjának és az önértelmező szereptudatnak akár indirekt leíró szándékával is) oly kísérlet, melyre egyetlen kötet nem is lehet teljes válasz, csak egy hosszadalmasabb, kitartó, támogatott kutatás-sorozat egyik állomása. Még nem „Nagyállomás”, de már nem is csupán feltételes megálló. Folytatása, további szakkönyvek kiadása ezért is lehetne kulcsfontosságú. Meg hát nem utolsósorban azért, mert egyetlen kulcs sosem nyit minden megismerési kiskaput, értő szándékot, partnerségi horizontot. Ezeknek jövője viszont mindannyiunk belátási szándékától, érzékenységétől, tudományos igényességétől, méltóságtudatától lesz biztosítható. 